PRAGATI: Journal of Indian Economy

Volume 4, Issue 2, July-December 2017, pp. 120-129

doi: 10.17492/pragati.v4i02.11470

\title{
Diversification of Employment in the State of Punjab: Factors and Future Prospects
}

\author{
Gurinder Jit Singh Bhullar* and Harinder Mohan**
}

\begin{abstract}
This paper examines the diversification of the employment scenario in the state of Punjab by utilising secondary data sources collected from various government and nongovernmental sources. The results of the study show that the economy of Punjab has gone through the process of structural transformation which is revealed from the changing pattern of per capita contribution in net State Domestic Product. However, the economy of Punjab has not witnessed any transformation in terms of employment generation. In this sense, the rural population in the state of Punjab largely depends on the agricultural sector. The study also identified the major factors that contributed towards the non-farm employment generation in the state of Punjab. The empirical results of the study highlighted the level of education, values of non-farm assets, and the distance of the village from the nearest town as the major contributors towards rural non-farm sector. Based on the findings, the study suggests that efforts should be made to enhance infrastructural facilities to enhance the participation in the non-farm activities. Along with this, there is a dire need to strengthen the farm and non-farm linkages to enhance better opportunities for employment in rural areas of Punjab.
\end{abstract}

Keywords: Diversification; Non-farm employment; Infrastructure.

\subsection{Introduction}

The process of diversification defines the production of a variety of different articles, services, etc. often as a safeguard against the effects of fall in demand for a particular product. In simple words, diversification refers to the participation in more than one activity at one point of time with the objective to enhance level of living and reduce risk, and uncertainty in business activity.

*Corresponding author; Assistant Professor in Economics, Guru Nanak College, Moga, Punjab, India.(Emailid: gjs_bhullar@yahoo.co.in)

**Assistant Professor in Economics, Guru Nanak College, Moga, Punjab, India. (Email ID: harindermohan11@gmail.com) 
More specifically, diversification generates additional business activities with the help of sophisticated production technology. It reflects transformation of product as well as input choice in any kind of business activity (Pingali and Rosegrant, 1995). The process of diversification has two important components. First assumes perfect knowledge and the second is to downsize the risk by adopting multiple business activities (Dorsey, 1999). The adoption of diversification help farmers and farm managers to apply multiple combinations of activities to decrease fluctuations of farm income. (Mishra and El-Osta, 2002). The successful implementation of diversification process requires heterogeneity in farm resources like soil and land resources.

With regard to agriculture, the process of diversification is divided into four stages. Firstly, at the cropping level, diversification includes adoption of commercial crops. Most of the developing countries are going through this stage. The second stage starts when farmers start producing and selling multiple crops at different points of time (Metcalf, 1969). Next, mixed farming takes place in the process of diversification. At last, agro based activities start supporting conventional agricultural practices.

The major factors accounting for the start of diversification process are shifts in the governmental policies, increase in profitability, development of market infrastructure and minimum support price mechanism. The crops like spices and medical herbs which do not have high volume provide better scope of crop diversification. At the national level, the process of diversification is beign largely adopted in rainfed areas along with the areas with distinct soil problems. The significance of diversification can also be drawn from improving bio-diversity at the national as well as state level. Thus diversification can prove very helpful in achieving the national goal of sustainable development.

In a nutshell, it can be maintained from the above discussion that diversification help farmers to enhance their income sources through adoption of new methods of cultivation along with additional employment opportunities. Therefore, diversification of agricultural sector can solve different agrarian problems being faced by the rural economy of Punjab (Bhullar and Sidhu, 2006).

The major objective of the present paper is to determine the correlates of employment diversification in the state of Punjab. The whole study is divided into five sections. Section 1 is introductory in nature. Section 2 gives a brief review of literature related to the theme of the paper. Research methodology of the paper is discussed in section 3 and results of the study are given in section 4. Conclusions and policy perceptions are discussed in section 5 . 


\subsection{Review of Literature}

Insofar as the determinants of rural non-agricultural employment are concerned, few hypotheses have been put forward and tested on the basis of empirical data. Among these, three hypotheses are more popular. The first hypothesis deals with the interlinkages between demand and supply resulting from a growing agriculture or agricultural led diversification (Mellor, 1976). Second, hypothesis deals with residual sector hypothesis, which envisages that non-farm sector acts as a sponge to absorb surplus labour force due to distress conditions in rural farm activities (Singh, 2007). Third, hypothesis investigates inverted $U$ time path hypothesis which deal with simultaneous operation of both pull as well as push factors affecting rural non-agricultural employment. In net terms, the growth of rural non-agricultural employment activities has been broadly attributed to two factors. First, agriculture-growth led diversification, (ii) distresses-induced diversification. On the basis of these hypotheses, various research scholars, economists examined determinants of non-farm employment and income at both micro and macro levels and few of them have been discussed below;

Kumar (2007) focused her study on various issues pertaining to the nature of non-agricultural employment and its major determinants in rural areas of Uttar Pradesh by using population census data for the period 1991-2001. The study hypothesized rural diversification as an essential part of rural transformation. To evaluate causes of structural changes in the state, the study used cross sectional district level multiple regression analysis, whereas, to indentify factors associated with off-farm employment in rural areas of Uttar Pradesh the correlation matrix of dependent and independent variables had been worked out. The major factors affecting participation in nonagricultural sector were gross value added as per capita of rural population, proportion of BPL households, average size of operational holdings, electricity consumed in agriculture, number of tractors and electric pump sets etc. The findings of the study noted that off farm activities shown significant growth in the studied areas. Further the study noted that urbanization, use of electric pumps, average size of land holdings and literacy rate explained 91.6 percent of variations in rural non-farm employment.

Vatta and Sidhu (2007) utilised household level data to examine the employment trends and diversification of income along with their determinants by utilizing primary data of 315 rural households for the reference period 2002. The study also sought to analyse the likely impact of rural non-farm diversification on level of poverty by assessing the contribution of various variables related with rural non-farm activities. To examine correlates of income diversification of a rural household the study utilized Ordinary Least Square (OLS) technique. Major determinants included were, family size 
in number, operational area, land productivity in the village, incidence of non-farm employment in the family and worker population ratio in the family. Further, the relationship between income diversification, household income and poverty had been computed with simple correlation coefficients. On the basis of the empirical analysis, the study noted that most of the explanatory factors exhibited a negative relationship with rural nonfarm employment and income. For example, the employment and incomes from rural non-farm sector shared a negative relationship with the level of ownership. Relatively poor rural households were found obtaining income from off-farm activities compared to those having medium and large land holdings. The income diversification was found to be positively influenced by the family size and worker population ratio in the families. On the other hand, the impact of caste and operational area was found to be negatively significant. Moreover, the study found that rural non-farm income sources failed to make any significant dent into rural poverty among the rural households. Finally, the study suggests the wide scope to enhance the development of dairying, construction, manufacturing and trade, which can lead to more remunerative employment sources in the rural areas. This can only be done through appropriate policy mix aimed at the skill formation among the rural poor by better education and vocational training of the rural youth.

Abraham (2011) analysed the correlates of rural off-farm diversification in the rural economy of India during 2010-11. The author noted that the importance of rural non-farm activities has increased manifold during recent past. It was observed that though the role and scale of non-farm activities has increased manifold during past three decades, most of such diversification occurred during the period of severe agrarian distress. Thus, in net terms the trends and patterns in the structural shift support the argument of distress diversification response to crises. To find the major pull and push factors of such diversification the study utilized Logit and multinomial Logit estimates. The major factors included were age, sex, educational level, size of land holdings, size of household and monthly per capita expenditure etc. The study showed that both push and pull factors are accounted for structural diversification in rural parts of India.

\subsection{Research Material and Methodology}

The data for the proposed study are collected from various secondary sources collected from different governmental and non-governmental reports, books, journals, articles etc. pertaining to different time periods. Logistic regression model has been utilized to find the correlates of off-farm employment in rural areas of Punjab. 


\section{Description of Risk Factors}

\begin{tabular}{|c|c|c|}
\hline Sr. No. & Variables & Named \\
\hline 1 & Age of the household head & $\mathrm{X}_{1}$ \\
\hline 2 & Household Size & $\mathrm{X}_{2}$ \\
\hline 3 & Value of non-farm assets & $\mathrm{X}_{3}$ \\
\hline 4 & Monthly per capita-food expenditure & $\mathrm{X}_{4}$ \\
\hline 5 & Monthly per capita non-food expenditure & $\mathrm{X}_{5}$ \\
\hline 6 & Level of education & $\mathrm{X}_{6}$ \\
\hline 7 & Distance from the nearest town & $\mathrm{X}_{7}$ \\
\hline 8 & Gender of the head of household $\mathrm{X} 8$ & $\mathrm{X}_{8}$ \\
\hline 9 & Constant & $\mathrm{X}_{9}$ \\
\hline
\end{tabular}

The unknown parameter of the logistic regression model, that is, $\beta_{0}, \beta_{1}, \ldots, \beta_{9}$ has been estimated by utilizing the iterative maximum likelihood method.

We express the logistic regression model in terms of link function in which the model can act as a generalized linear model. This is achieved by taking log odds of the predicted risk, i.e.

$$
\mathrm{Y}=\log [\mathrm{P} /(1-\mathrm{P})]=\beta_{0}+\beta_{1} \mathrm{X}_{1}+------+\beta_{9} \mathrm{X}_{9}
$$

Thus, the log odds have a linear relationship.

\subsection{Results and Discussion}

It can be seen from Table 1 that the share of off-farm activities in NSDP has increased during the last three decades. For instance, the contribution of primary sector was recorded 34.60 percent of in 2004-15 to 23.03 per cent in 2012-13 and further to 22.42 per cent in 2013-14. The respective contribution of off-farm activities has registered increasing trends during the same period. This fact points towards the rising importance of off-farm activities in Punjab.

Table 2 presents sex-wise distribution of rural workers in Punjab during 1983 to 2004-05. It is seen from Table 2 that during the period 1993-94 to 2004-05, rural female workforce participation rate has increased from 22.0 per cent in 1993-94 to 32.2 per cent in 2004-05. On the other hand, workforce participation rate for males found declining till 1999-2000 after it again increased to 54.9 per cent in 2004-05. In net terms, workforce participation rate has shown slight improvement during various NSS rounds. Such trend shows the dismal performance of employment scenario in the state of Punjab. 
Table 1: Contribution of off-Farm Activities in Net State Domestic Product (NSDP) in Punjab at Constant (2004-05) Prices (Figures in Percentage)

\begin{tabular}{|c|c|c|c|c|c|c|c|}
\hline Sector & $\begin{array}{l}\text { 2004- } \\
05\end{array}$ & $\begin{array}{l}\text { 2008- } \\
09\end{array}$ & $\begin{array}{l}\text { 2009- } \\
10\end{array}$ & $\begin{array}{l}\text { 2010- } \\
11\end{array}$ & $\begin{array}{l}2011- \\
12(R)\end{array}$ & $\begin{array}{l}\text { 2012- } \\
13(P)\end{array}$ & $\begin{array}{l}2013- \\
14(Q)\end{array}$ \\
\hline Agriculture and Livestock & 32.95 & 26.93 & 25.00 & 23.73 & 22.78 & 21.74 & 21.14 \\
\hline Agriculture & 21.81 & 17.42 & 16.15 & 15.19 & 14.54 & 13.59 & 13.05 \\
\hline Livestock & 11.14 & 9.51 & 8.85 & 8.54 & 8.24 & 8.15 & 8.09 \\
\hline Forestry and Logging & 1.37 & 1.16 & 1.13 & 1.09 & 1.08 & 1.09 & 1.08 \\
\hline Fishing & 0.28 & 0.23 & 0.24 & 0.22 & 0.21 & 0.20 & 0.20 \\
\hline Agril. \& Allied & 34.60 & 28.32 & 26.37 & 25.04 & 24.07 & 23.03 & 22.42 \\
\hline Mining and Quarrying & 0.02 & 0.02 & 0.02 & 0.02 & 0.01 & 0.00 & 0.00 \\
\hline (Overall Primary Sector) & 34.62 & 28.34 & 26.39 & 25.06 & 24.08 & 23.03 & 22.42 \\
\hline Manufacturing & 14.02 & 17.87 & 19.26 & 19.79 & 19.01 & 18.59 & 17.99 \\
\hline Registered & 5.88 & 9.11 & 10.57 & 1109 & 10.50 & 10.19 & 9.79 \\
\hline Un-registered & 8.14 & 8.76 & 8.69 & 8.70 & 8.51 & 8.40 & 8.20 \\
\hline Construction & 7.02 & 8.47 & 8.28 & 7.85 & 7.39 & 7.19 & 6.86 \\
\hline $\begin{array}{l}\text { Electricity, Gas and Water } \\
\text { Supply }\end{array}$ & 1.94 & 2.40 & 2.26 & 2.13 & 1.96 & 1.89 & 1.84 \\
\hline (Secondary Sector Sub-total) & 22.98 & 28.74 & 29.80 & 29.77 & 28.36 & 27.27 & 26.69 \\
\hline Total Industry (Secondary) & 23.00 & 28.76 & 29.82 & 29.79 & 28.37 & 27.67 & 26.69 \\
\hline $\begin{array}{l}\text { Transport, Storage and } \\
\text { Communication }\end{array}$ & 5.88 & 6.22 & 6.31 & 6.19 & 6.31 & 6.37 & 6.35 \\
\hline Railways & 0.78 & 0.87 & 0.82 & 0.68 & 0.77 & 0.76 & 0.75 \\
\hline Other transport means & 3.14 & 2.92 & 29.92 & 2.83 & 2.89 & 2.94 & 2.95 \\
\hline Storage & 0.42 & 0.32 & 0.34 & 0.32 & 0.33 & 0.36 & 0.35 \\
\hline Communication & 1.54 & 2.11 & 2.23 & 2.36 & 2.32 & 2.31 & 2.30 \\
\hline Trade and Hotels & 13.20 & 12.26 & $11 . .89$ & 12.19 & 12.36 & 12.53 & 12.66 \\
\hline Banking and Insurance & 5.00 & 7.08 & 7.74 & 8.62 & 10.54 & 11.48 & 12.67 \\
\hline $\begin{array}{l}\text { Real Estate and Business } \\
\text { Services }\end{array}$ & 4.65 & 3.94 & 3.72 & 3.56 & 3.46 & 3.39 & 3.29 \\
\hline Public Administration & 4.43 & 4.45 & 4.69 & 465 & 4.72 & 4.90 & 4.98 \\
\hline Other Services & 9.24 & 8.97 & 9.46 & 9.96 & 10.17 & 10.63 & 10.94 \\
\hline Sub-Total of Tertiary & 42.40 & 42.92 & 43.81 & 45.17 & 47.56 & 49.30 & 50.89 \\
\hline State Domestic Product & 100.00 & 100.00 & 100.00 & 100.00 & 100.00 & 100.00 & 100.00 \\
\hline
\end{tabular}

Source: Statistical Abstract of Punjab, various issues.

R: Revised, P: Provisional, Q: Quick Estimates.

Table 3 gives the distribution of workers in the rural areas of Punjab during various NSS rounds. The analysis of the table highlighted that the share of male workforce has increased from 22.3 per cent in 1983 to 36.0 per cent in 1999-2000 and further to 45.3 per cent in 2004-05. For females the respective share, on the other hand, 
has increase from 7.2 per cent in 1983 to 9.3 per cent in 1999-2000 and further to 10.3 per cent in 2004-05. In net terms the share of male non-farm workers has registered an increase of 23 percentage points during 1983 to 2004-05, whereas for females, rural nonfarm workforce has registered an increase of only 3.1 percentage points during the same period.

Table 2: Sex-wise Distribution of Rural Workers Usual Status (PS+SS) in Punjab during 1983 to 2005

\begin{tabular}{|l|c|c|c|l|l|l|l|l|c|}
\hline \multicolumn{1}{|c|}{ Year } & \multicolumn{3}{|c|}{ Male } & \multicolumn{3}{c|}{ Female } & \multicolumn{3}{c|}{ Person } \\
\hline & Ps & Ss & All & Ps & Ss & All & Ps & Ss & All \\
\hline 1983 & 54.9 & 3.2 & 58.1 & 41.0 & -9.1 & 31.9 & 37.8 & 7.2 & 45.0 \\
\hline $1993-94$ & 54.2 & 0.4 & 54.6 & 3.7 & 18.3 & 22.0 & 30.3 & 8.9 & 39.2 \\
\hline $1999-2000$ & 52.6 & 0.4 & 53.0 & 4.0 & 24.0 & 28.0 & 29.2 & 11.8 & 41.0 \\
\hline $2004-05$ & 54.2 & 0.7 & 54.9 & 4.2 & 28.0 & 32.2 & 30.3 & 13.7 & 44.0 \\
\hline
\end{tabular}

Source: NSSO Reports of $38^{\text {th }}, 50^{\text {th }}, 55^{\text {th }}$ and $61^{\text {st }}$ Rounds

PS: Principal Status, SS: Subsidiary Status

Table 3: Distribution of Rural Non-Farm Workers (Usual Status: Principal + Subsidiary Status) in Punjab 1983-2004-05

\begin{tabular}{|c|l|c|c|}
\hline NSS Round & Year & Male & Female \\
\hline $38^{\text {th }}$ & 1983 & 22.3 & 7.2 \\
\hline $43^{\text {rd }}$ & $1987-88$ & 30.3 & 8.3 \\
\hline $50^{\text {th }}$ & $1993-94$ & 31.9 & 7.3 \\
\hline $55^{\text {th }}$ & $1999-2000$ & 36.0 & 9.3 \\
\hline $61^{\text {st }}$ & $2004-05$ & 45.3 & 10.3 \\
\hline
\end{tabular}

Source: Kamal Vatta and B.R. Garg (2008)

Table 4 shows that rural workforce in primary sector was registered 82 per cent in 1983 as against 7.9 per cent in secondary sector. The share of employment in services sector was found highly urban in nature during the same time period. The rural primary sector employment declined to 74.7 percent in 1993-94 from 82.0 percent in 1983 . The respective share in tertiary sector ncreased to 15.8 per cent at rural level and 59.9 percent at urban level in 1993-94. The New Economic Reforms has put significant impact on the participation of rural workers in Off-farm activities. The participation in the industrial sectors too started witnessing increasing trends soon after the commencement of economic reforms. 
Table 4: Sectoral Distribution of Usual Status Workers in Punjab by Region during 1983 to 2004-05

\begin{tabular}{|l|l|l|l|l|l|l|l|}
\hline Year & & \multicolumn{3}{|c|}{ Rural } & \multicolumn{3}{c|}{ Urban } \\
\hline & Round & Primary & Secondary & Tertiary & Primary & Secondary & Tertiary \\
\hline 1983 & $38^{\text {th }}$ & 82.0 & 7.9 & 9.4 & 13.6 & 31.2 & 52.8 \\
\hline $1993-94$ & $50^{\text {th }}$ & 74.7 & 9.6 & 15.8 & 9.3 & 30.8 & 59.9 \\
\hline $1999-00$ & $55^{\text {th }}$ & 72.6 & 12.0 & 15.5 & 8.7 & 30.1 & 61.3 \\
\hline $2004-05$ & $61^{\text {st }}$ & 67.0 & 16.9 & 13.3 & 5.9 & 34.6 & 59.6 \\
\hline
\end{tabular}

Source: NSSO, Various Rounds

Thus it can be maintained from above discussion that the work participation in Punjab has been moving from primary and tertiary sectors towards secondary sector at both the levels.

The logistic results of the factors associated with the non-agricultural employment in Punjab are given in Table 5. The variables included in the model are casre of the households, gender of the head of household, distance from the nearest town, number of dependents, level of education, monthly food expenditure, monthly non-food expenditure and values of non-farm assets.

Table 5: Logit Estimates of Rural Non-Farm Employment in the State of Punjab, 2016

\begin{tabular}{|c|l|r|r|r|r|r|r|}
\hline $\begin{array}{c}\text { Sr. } \\
\text { No. }\end{array}$ & \multicolumn{1}{|c|}{ Explanatory Factors } & B & S.E. & Wald & Df & Sig. & Exp(B) \\
\hline 1 & Age of the head of the household X1 & $.084^{* *}$ & .016 & 29.287 & 1 & .000 & 1.088 \\
\hline 2 & Size of the household X2 & $.293^{*}$ & .109 & 7.239 & 1 & .007 & 1.340 \\
\hline 3 & Value of non-farm assets X3 & $.000^{* * *}$ & .000 & 3.383 & 1 & .066 & 1.000 \\
\hline 4 & Monthly per capita-food expenditure X4 & $.000^{* * *}$ & .000 & 16.736 & 1 & .000 & .999 \\
\hline 5 & Monthly per capita non-food expenditure X5 & $.001^{* * *}$ & .000 & 33.408 & 1 & .000 & 1.001 \\
\hline 6 & Level of education X6 & $.054^{* *}$ & .031 & 3.127 & 1 & .077 & 1.055 \\
\hline 7 & Dist(1) X8 & $.032^{* *}$ & .261 & .015 & 1 & .902 & 1.033 \\
\hline 8 & Gender of the head of household X9 & $.311^{*}$ & .727 & .182 & 1 & .669 & 1.364 \\
\hline 9 & Constant & -6.174 & .988 & 39.074 & 1 & .000 & .002 \\
\hline
\end{tabular}

Table 5 gives the logit estimates of off-farm employment in the rural areas of Punjab. The logit estimates revealed that level of higher education, household size, gender of household head and age of the household head has put significant impact on the participation in rural non-agricultural employment in Punjab. 


\subsection{Concluding Remarks and Policy Implications}

This paper examines the diversification of the employment scenario in the state of Punjab by utilising secondary data sources collected from various governmental and non-governmental sources reports. The results of the study showed that the economy of Punjab has gone through the process of structural transformation which is revealed form the changing pattern of per capita contribution in net state domestic product. However, the economy of Punjab has not witnessed any transformation in terms of employment generation. Thus, agricultural sector still remains major sector for rural livelihood for the large chunk of rural population in Punjab. The study also identified the major factors that contributed towards the non-farm employment generation in Punjab. The results of Logistic analysis highlighted that the educational level, values of non-farm assets, distance of the village from the nearest town significantly impacted the participation in non-farm activity. On the basis of the findings the study suggested that efforts should be made to enhance infrastructural facilities to enhance the participation in the non-farm activities. Along with there is dire need to strengthen the farm- non-farm linkages to enhance more opportunities for employment particularly in rural areas of Punjab.

\section{References}

Abraham, Vinoj (2011). Employment growth in rural India: Distress driven. Economic and Political Weekly, XLIV(16), 97-104.

Bhullar, A.S. \& Sidhu, R.S. (2006). Integrated land and water use: A case study of Punjab. Economic and Political Weekly, 41(52), 5353-57.

Dorsey, B. (1999). Agricultural Intensification, Diversification and Commercial

Production among Small Holder Coffee Growers in Central Kenya. Economic Geography, 75(2), 178-195.

Government of Punjab, (2010, 2012, 2014). Statistical Abstract of Punjab. Economic and Statistical Organization, Chandigarh.

Kumar, N.P. (2007). Trends in rural diversification and its determinants in Uttar Pradesh. The Indian Journal of Labour Economics, 50(4), 703-714. 
Metcalf, D. (1969), Labour productivity in English agriculture, 1850-1974: A theoretical comment. The Economic History Review, 22(1).

Mellor, J. W. (1976). A strategy for India and the developing world. A Twentieth Century Fund Study. Cornell University Press.

Mishra, A.K. \& Elosta, H. S. (2002). Managing risk in agriculture through hedging and crop insurance. What does a national survey reveal. Agricultural Finance Review, 62(2), $35-148$.

Pingali, P. L. \& Rosegrant, M. W. (1995). Agricultural commercialisation and diversification process and policies. Food Policy. 20(3), 171-185.

Singh, S. (2007). Flow of funds to farmers and indebtedness in Punjab. Research Report, The Punjab State Farmer's Commission, Government of Punjab.

Vatta, K. \& Sidhu, R.S. (2007). Income diversification among rural households in Punjab: Dynamics, impacts and policy implications. The Indian Journal of Labour Economics, 50(4), 723-736.

Vatta, K. \& Garg, B. R. (2008). Rural non-farm sector in Punjab: Pattern and access to employment and income. Indian Journal of Agricultural Economics, 63(2), 224-243. 